\title{
Ecological problems of water resources in Kazakhstan
}

\author{
Turgai Alimbaev ${ }^{1}$, Bibizhamal Omarova ${ }^{2}$, Samal Tuleubayeva ${ }^{3}$, Bekzhan Kamzayev², \\ Nurmuhammed Aipov, Zhanna Mazhitova, ${ }^{2, *}$ \\ ${ }^{1}$ Buketov Karaganda State University, Karaganda, Republic of Kazakhstan \\ ${ }^{2}$ Astana Medical University, Nur Sultan, Republic of Kazakhstan \\ ${ }^{3}$ L.N. Gumilyov Eurasian National University, Nur Sultan, Republic of Kazakhstan
}

\begin{abstract}
This paper proposes a solution to the environmental problems in the Republic of Kazakhstan associated with the provision of the population with quality water. The authors propose to use only clear scientific forecasts, practical ecological scenarios, as well as the methodology of the National Action Plan for Environmental Protection and Sustainable Development. This will allow to solve the issues of desertification, salinization, water scarcity, decline in irrigation, agriculture, and the fishing industry in the future. The purpose of the article is to reveal the reasons for the insufficiency and unevenness in the provision of water resources in the republic. In the study the principle of historicism and systems analysis is used. The results of the research confirm and indicate that the growth of the economic potential in industry and the transition to market mechanisms for the development of the economy gave rise to a reduction in reserves of clean water, shallowing of mountain and transboundary rivers, the decrease in fish populations, and the emergence of a real threat of a water ecological crisis in the republic. The obtained theoretical results of the study can be applied when discussing and significantly improving the environmental issues of water resources in the country.
\end{abstract}

\section{Introduction}

Water supply is one of the strategic state tasks of Kazakhstan. Having a vast territory, a diversified national economic complex, the Republic of Kazakhstan is experiencing an insufficient and uneven supply of water resources. Therefore, the issues of restoration and rational use of water in the republic are relevant. Kazakhstan, being in the center of the Eurasian continent, is a water-deficient country. There are eight river basins in Kazakhstan, i.e., Balkhash-Alakol, Shu-Talass, Aral-Syrdarya, Ural-Caspian, Tobol-Torgaysky, Ishim, Irtysh and Nura-Sarysu. A total of 86 water management areas have been identified on the territory of the republic. There are from 5 to 12 and more water management areas within one water basin. The situation with the provision of surface and groundwater resources in individual regions of the republic is significantly different. The basin of the Ertis river and

\footnotetext{
*Corresponding author: mazhitova_69@mail.ru
} 
the Balkhash-Alakol basin are better provided with their own resources of both surface and groundwater. The Nura-Sarysu, Esil and Tobol-Torgai basins are deficient in terms of groundwater. Significant areas of the Esil, Zhaiyk-Caspian, Aral-Syrdarya, Tobol-Torgai and Nura-Sarysu basins are already experiencing a shortage of both surface and groundwater [1]. So, for example, in Nura-Sarysu, which is a water basin in the center of Kazakhstan, the development of productive forces developed for a long time without taking into account the ecological characteristics of the region with an increase in deformations of sectoral proportions and socio-economic structure. All this led to a serious aggravation of the environmental situation not only in industrial centers, but throughout the region as a whole. Almost no city in this region at the end of the twentieth century was provided with drinking water of the required quality. Environmental pollution has affected the quality of food. The morbidity and mortality of the population increased, especially in childhood. The industry structure that has developed in this region has become the main reason for a fairly wide range of environmental problems, the nature of which, in turn, was largely due to the activities of a particular production complex and the degree of their impact on the quality of surface and ground waters. The concentration of Central Kazakhstan enterprises of coal, non-ferrous and ferrous metallurgy, chemistry, mechanical engineering, the growth of the network of transport highways and numerous communications, as well as a high degree of urbanization, developed agriculture determined the formation of a significant level of pollution of all components of the environment. As a result, Central Kazakhstan has been traditionally one of the regions with the highest specific indicators for the emission of pollutants into the atmosphere, the discharge of polluted wastewater. The region accounts for $16 \%$ of industrial and $13 \%$ of agricultural production in Kazakhstan, more than $44 \%$ of fish catch, $75 \%$ of forage lands.

At the present stage an important factor determining not only the ecological situation, but also the development of productive forces, is the state of water resources. The state of water resources is of serious concern. The huge volumes of discharged water led to special requirements for treatment plants, the effluents from which were directly discharged into water bodies. However, many urban wastewater treatment plants have been operating with significant overload in recent years. The main part of the polluted wastewater passing through them was recognized by the inspecting authorities as insufficiently treated, i.e. not meeting the quality of drinking water. This circumstance has caused the need to assess the sanitary state of water bodies in the region and predict the water use of the population, including organizing strict control over the content of chemicals present in water due to industrial, agricultural and domestic pollution. It should be noted that the long-term pollution of the Nura River with hazardous waste discharged by the Karaganda Metallurgical Plant will have a negative impact on the environment for a long time due to secondary pollution of the river by bottom sediments accumulated over the previous years $[2]$.

\section{Materials and Methods}

The study is based on the general research principles of historicism and objectivity. Applying these methods in the research enables to consider scientific knowledge as an integral system in which each previous approach indirectly or directly influenced the next one. All this together made it possible to compile a systematic series of scientific and theoretical calculations on the given issue. The views of authors are discussed regardless of ethnocultural preferences and political inclinations, which necessitates a thorough comparison of facts and phenomena in aggregate, that is, a comprehensive study of the problem. 
In addition, a systematic approach, which takes into account both the features of the research objects themselves and the factors that determine these features, is used in the paper. Such approaches allow to identify not only gaps in the studied subject, but also some particular aspects of the problem that might not have come to the scholars' attention for one reason or another. In general, this gives the opportunity to objectively compare these aspects and, on their basis, determine the prospects for further research.

\section{Discussion of the results}

\subsection{Ecology of the Balkhash region}

Another serious problem is the ecology of the Northern Balkhash region. Lake Balkhash is the third after the Caspian Sea and the drying up Aral Sea, a drainless, inland water body of the earth, on the shore of which the giant of non-ferrous metallurgy is located named the Balkhash Copper Smelter. On the bank of the Karatal river a lead-zinc plant operates, exploration and development of open-pit mines of coal, polymetallic ores have been started, and light industry enterprises operate on the basis of local raw materials. Industrial facilities of the Northern Balkhash region are large and direct pollutants of the lake's waters, which discharge wastewater through the storm sewers of numerous tailing dumps and through the atmospheric air, where sulfuric anhydrite and other gases enter. For example, the Balkhash Mining and Metallurgical Plant discharges waste water into the Tarangalyk Bay. The concentration of copper in them reaches 35-48 maximum permissible concentrations (hereinafter - MPC), and in case of emergency emissions exceeds 300 MPC. In recent years of observations of the hydrochemical regime of watercourses, a widespread excess of sulfates MPC of fishery water bodies was recorded. For example, in the small Sary-Shagan, the sulfate content is 7.8-8.9 times higher than the MPC, in Bertys Bay it is 7.7-9.5 times higher than the MPC, and in the boundary section of Balkhash city it is 7.7-8.1 times higher than the MPC. The excess MPC of chloride is also observed in Small Sary-Shagan by 1.31.5 times, in Bertys Bay by 1.3-1.5 times and in the boundary section of Balkhash by 1.31.6 times. Characterizing the pollution of the lake Balkhash as a whole, the following picture is obtained. Chlorides, as a percentage of the total number of hydrochemical analyzes, exceed the maximum permissible concentration in $80.4 \%$ of cases, sulfates and copper - by $100 \%$, zinc - by $25.3 \%$, fluorides - by $98 \%$, petroleum products - by $40 \%$, phenols - by $33.3 \%$ of cases. The water of Lake Balkhash contains a long series of trace elements, among which heavy metals occupy a leading position. This is due to the geochemical features of the Balkhash region soil, as well as the influx of heavy metals into the rivers and Lake Balkhash with wastewater and partial deposition on the surface of the reservoir from air emissions from industrial facilities. The content of manganese, copper, zinc, barium, titanium, boron, nickel, zinc and cadmium in the water of Lake Balkhash exceeds the MPC for heavy metals for fishery reservoirs. There are serious concerns for the ecology of Lake Balkhash, especially regarding the possibility of a repetition of a disaster like the Aral. At the International Environmental Forum on Lake Balkhash in 2015, it was announced that the Kazakhmys corporation will complete the construction of an environmentally friendly production facility next year, which will reduce emissions by 80 $90 \%$. Over the past years, life has proved that the ecological situation in the basin of Lake Balkhash is still worsening [3].

Numerous studies on the consequences of human economic activity influence on natural systems indicate the emergence of complex environmental situations, mainly in large industrial centers, where various industrial enterprises cause irreparable damage to the environment, negatively affecting the soil, vegetation, water bodies, the atmosphere and 
humans. The dominance of economic tasks led to a mostly formal, declarative nature of measures for environmental protection, which were of an administrative-prohibitive, economically contradictory nature. At the beginning of the twenty-first century, the consumption of water by industry, as well as by agriculture, reached enormous proportions. Moreover, pollution of water systems began to pose a much greater danger than pollution of the atmosphere, due to the fact that, firstly, the processes of regeneration or self-purification proceed much slower in the aquatic environment than in the air; secondly, the sources of pollution of water bodies are more diverse; thirdly, natural processes occurring in the aquatic environment and exposing to pollution are more sensitive in themselves and are of greater importance for the maintenance of life on Earth than those that occur in the atmosphere.

\subsection{Sary-Arka and water resources}

The state of the Sary-Arka water basins also poses a real threat to the future of people, especially in areas of chemical and petrochemical industries concentration, which entail the removal of harmful substances with an extremely complex and dangerous structure. In the last decades of the twentieth century the reservoirs of the region were under triple pollution: transit (background), discharged regional drains and emergency discharges. According to environmental authorities, most industrial enterprises did not have a sufficient degree of local cleaning that would meet sanitary requirements. Insufficiently organized storm sewerage in many cities caused the discharge of surface water without purification from industrial, residential areas and highways into water bodies, turning into a significant source of pollution of open water bodies with suspended ether-soluble substances, heavy metal ions, etc. A difficult situation developed in the Nura river basin. The quality of water resources, assessed by ecologists as "polluted", was influenced by the discharge of insufficiently treated effluents from adjacent enterprises, as well as the transit of polluted waters. The most negative impact on the aquatic environment was exerted by enterprises of housing and communal services (40\%), energy (26\%), chemical and metallurgical industries (13\%), coal industry and agriculture (8\%). Many small rivers have been significantly polluted by water waste. Due to the significant inflow of household, agricultural and industrial wastewater, waste discharges from enterprises of the chemical and metallurgical complex, the Nura river has become the most polluted in the Karaganda region. It is indicative that the long-term pollution of the river by waste discharged by the Karaganda Metallurgical Plant will have a negative impact on the environment for a long time due to secondary pollution of the river by bottom sediments accumulated over previous years $[4,5]$. The huge volumes of discharged water led to special requirements for treatment plants, the effluents from which were directly discharged into water bodies. However, many urban wastewater treatment plants have been operating with significant overload in recent years. The main part of the polluted wastewater passing through them was recognized by the inspecting authorities as insufficiently treated, i.e. not meeting the quality of water. This circumstance has caused the need to assess the sanitary state of water bodies in the region and predict the water use of the population, including organizing strict control over the content of chemicals present in water due to industrial, agricultural and domestic pollution. Thus, despite the measures taken, the environmental situation remained tense. Departmental interests continued to determine the nature of the development of productive forces, an irrational way of resources utilization.

A slight decrease in the volume of wastewater disposal was facilitated by the efficient operation of technological equipment at Kazakhmys Energy LLP, a decrease in the production of the main products types of ArcelorMittal Temirtau JSC, as well as the full implementation of the Bassel Group LLS LLP production program. The volume of 
pollutants discharged into water bodies in 2018 decreased by $5.4 \%$ and amounted to 432.75 thousand tons. The decrease in the volume of discharges of pollutants is also associated with a decrease in industrial discharges of JSC "CentralAsia Cement" due to the use of twostage cleaning in 2 sedimentation tanks. Pollution of water resources and discharges of pollutants with wastewater are shown in table 1 [6].

Table 1. Pollution of water resources and discharges of pollutants with waste water.

\begin{tabular}{|c|c|c|c|}
\hline $\begin{array}{c}\text { Actual volumes of } \\
\text { discharges }\end{array}$ & $\mathbf{2 0 1 7}$ & $\mathbf{2 0 1 8}$ \\
\hline \multirow{2}{*}{ Industrial discharges } & $\begin{array}{c}\text { Water disposal volume } \\
\text { mln m3 }\end{array}$ & 1172.734 & 1152.516 \\
\cline { 2 - 4 } & $\begin{array}{c}\text { The volume of pollutants, } \\
\text { thousand tons }\end{array}$ & 412.5 & 382 \\
\hline \multirow{2}{*}{\begin{tabular}{c} 
Domestic waste water \\
\cline { 2 - 4 }
\end{tabular}} & $\begin{array}{c}\text { Water disposal volume } \\
\text { mln m3 }\end{array}$ & 152.432 & 155.567 \\
\hline & $\begin{array}{c}\text { The volume of pollutants, } \\
\text { thousand tons }\end{array}$ & 44.3 & 47 \\
\hline $\begin{array}{c}\text { Emergency and } \\
\text { unauthorized } \\
\text { discharges }\end{array}$ & $\begin{array}{c}\text { Water disposal volume } \\
\text { mln m3 }\end{array}$ & 2.4 & 3.1 \\
\cline { 2 - 4 } & $\begin{array}{c}\text { The volume of pollutants, } \\
\text { thousand tons }\end{array}$ & 0.7569 & 1311.184 \\
\hline \multirow{2}{*}{$\begin{array}{c}\text { Total (all of the above } \\
\text { discharges) }\end{array}$} & $\begin{array}{c}\text { Water disposal volume } \\
\text { mln m3 }\end{array}$ & 1327.567 & 432.75 \\
\cline { 2 - 4 } & $\begin{array}{c}\text { The volume of pollutants, } \\
\text { thousand tons }\end{array}$ & 457.55 & \\
\hline
\end{tabular}

\subsection{Ecology of the Caspian region}

The ecological situation in the Caspian region is determined by the rise in the level of the Caspian Sea and anthropogenic impact on marine coastal ecosystems. The world's largest developed oil and gas fields, i.e., Tengiz, Karachaganak, Kashagan, as well as a network of river and seaports in the Caspian Sea, i.e., Republican State Enterprise "Aktau International Sea Trade Port", Atyrau, Bautino, Kuryk are located on the coast of this sea. In addition, the region has a well-developed network of oil and gas pipelines of Kaztransoil JSC, KazTransGas JSC, the Caspian Pipeline Consortium, as well as power lines. There are many thermal power plants and gas turbine power plants in operation. The presence of rich mineral deposits creates conditions for the growth of the region's economy. The basic industry is the oil and gas industry, which accounts for about $60 \%$ of the industrial potential of the region. Today it is generally accepted that at least until the end of the third decade of the 21 st century the oil and gas industry of the Republic of Kazakhstan will be the only driving force that will be able to bring the Kazakhstani economy to the forefront of the world community and ensure fundamental changes in all spheres of life of the population of the republic. The West of Kazakhstan has long been one of the most promising oil and gas regions. Almost all deposits of hydrocarbon raw materials that are in the stage of industrial development are concentrated here. At the moment, in terms of proven oil reserves, Kazakhstan is among the 15 leading countries in the world, and significant reserves of hydrocarbon raw materials make up $3.3 \%$ of the world reserves [7]. Large-scale development of oil and gas fields characterized by a high content of toxic elements, the presence of the world's largest closed body of water - the Caspian Sea and a number of transit rivers - the Volga, Zhaiyk (Ural), Emba and others further aggravated the ecological situation, demanded more attention to matters of environmental protection. The level of the Caspian Sea was subject to fluctuations and largely depended on the water systems of the 
rivers feeding it and meteorological conditions. A dangerous hydrological phenomenon was observed here, i.e., wind surges of the waters of the Caspian Sea. Such surges were repeated annually in the spring and autumn months. At the same time, significant areas were exposed to flooding. In addition to the fact that such surges caused great material damage, they were dangerous and environmentally friendly. When the territories of oil fields were flooded, the sea waters were polluted with oil products, which adversely affected the inhabitants of the sea, marine vegetation and microflora. The danger of flooding forced the construction of branch canals, dams and a number of other expensive protective structures.

The Caspian Sea is known for its rich biological resources. 90\% of the world's sturgeon stocks are concentrated here. The shallow waters of the Caspian Sea were a nesting place and a stopover for a huge number of waterfowl. The Caspian coast was a resort area of the republic, the Ustyurt reserve was created here. A variety of mineral complexes have been discovered in the region. Involving them in their use is connected with a number of environmental problems. In particular, a feature of the explored Karachaganak gas and oil condensate, Tengiz oil and a number of other oil and gas fields was the high content of hydrogen sulfide and other sulfur compounds, which increased the environmental hazard during their development. The increase in oil and gas production is accompanied not only by an increase in the rate of withdrawal of non-renewable natural resources, but also by the introduction of harmful hydrocarbon pollutants into the environment, among which the most dangerous are crude oil, gas condensates, oil sludge, acid tars and other hazardous substances. As a result of active pollution, there is a change in the chemical and physicochemical properties of the soil, a violation of the hydrological regime of territories, impoverishment and changes in the species composition, structure and productivity of phytocenosis, a decrease in the spatial distribution and number of animal populations. Loss of biological diversity is currently a real environmental threat [8]. Often in the process of violation in production techniques, transportation and processing of oil, especially during emergencies in which oil and gas emissions occur, there is environmental pollution the with oil and oil products, saline formation waters, drilling fluids, chemical reagents, which leads to a violation in environmental balance of natural ecosystems. As evidenced in practice, in Western Kazakhstan there is a process of active development of new hydrocarbon deposits, accompanied by geological exploration, drilling and construction works, laying of pipelines, roads, growth of settlements, which, in turn, has a strong anthropogenic impact on all components of the environment. In other words, all technological processes of oil and gas production and related activities are potential sources of environmental pollution. Particularly, it is necessary to analyze the state of the territories adjacent to the places of exploration, development and operation of hydrocarbon deposits. Within a radius of 500800 meters nearly every drilling rig $70-80 \%$ of vegetation is destroyed. The construction and operation of wells is accompanied by the destruction of the soil cover by $80 \%$, contamination of the site with oil, drilling fluids and chemicals by $40 \%$. Soil contamination in some oil fields reaches a thickness of up to 10 meters [8].

It has been proven that, getting into the soil and water, oil brings with it a diverse set of chemical compounds that violate the existing biogeochemical balance in ecosystems such as a change in the physical state of the environment, a violation of its water-air regime, the introduction of toxic substances, a change in the structure of the soil, a violation of carbonnitrogen balance, change in the migration ability of individual microelements in the soil. The most severe and dangerous in terms of consequences is the pollution of ground and surface fresh waters, as well as pollution of the marine environment, as is the case in the Caspian Sea. For groundwater and surface water sources, pollutants are usually oil, drilling and oil sludge and waste water. For example, the cuttings formed during well drilling can contain up to $7.5 \%$ oil and up to $15 \%$ organic chemicals used in drilling fluids. In a 
relatively large volume, cuttings often accumulate during oil preparation. In this case, cuttings can contain up to $80-85 \%$ oil, up to $50 \%$ mechanical impurities, up to $67 \%$ mineral salts and $4 \%$ surfactants. When developing oil fields on the shelf, even under normal oil production, each drilling rig throws into the water: oil $-30-120$ tons, drill cuttings -150 400 tons, drill workings $-200-1000$ tons $[9,10]$. At present, about 70-90 thousand tons of oil hydrocarbons are annually supplied to the Caspian Sea with river runoff, and from the coasts -29 thousand tons. A high concentration of oil products is noted throughout the entire sea mass, especially in its upper layer, and traces of oil have been found over an area of more than 800 sq. $\mathrm{km}$ around offshore drilling platforms. On the territory of the region, the Caspian oil-producing region, especially the Atyrau and Mangistau regions, is subject to the strongest anthropogenic impact. To date, more than 4.3 million hectares of disturbed land have been identified here, including 1.5 million hectares of technogenic zones, 1.9 million hectares of degraded pastures, 0.6 million hectares of contaminated with oil products and 0.3 million hectares of land with radioactive contamination. The total area of oil pollution in Western Kazakhstan is 194 thousand hectares, and the volume of spilled oil is more than 5 million tons [11].

In general, it can be noted that there is a steady tendency towards the deterioration of the ecological situation in the Caspian basin in all available directions. A significant increase in oil production in recent years has naturally led to a sharp deterioration in the environmental situation in the region. The oil strategy, which is being successfully implemented today in Kazakhstan, has made it possible to increase oil production several times not only on land, but also in the Caspian Sea. As expected, this further increased the risk of contamination of the territory of the republic's water basin with such valuable raw materials as oil. The latter circumstance can lead to a violation of the ecological balance, to the occurrence of man-made emergencies associated with the ignition of oil, oil products, explosions of mixtures of hydrocarbon vapors with air. The main sources of oil pollution in the Caspian Sea are exploration and exploitation of oil fields, transportation of oil products, pollution due to emissions from oil fields, sinking of wells as a result of rising sea water levels and other factors. The degree of oil pollution in some parts of the sea can exceed the permissible level by 20 times, as a result of oil seepage during production and transportation. Such parts of the Caspian Sea as Tengiz and other areas of oil industry development are most affected by oil and oil products pollution.

Recently, new centers of oil production have been created in Western Kazakhstan. This negatively affected the ecological state of the region, since the oil produced here contains too much sulfur compounds, as well as mercaptans. Such oil has to be refined in a special way, which causes additional problems. When cleaning, it is necessary to take into account environmental standards to prevent pollution of the entire water area of the Caspian [12].

One of the reasons for the pollution in the Caspian Sea is the wreck of large oil tankers. Along with this, the release of used water during the movement of ships at sea also serves as a source of pollution. The most dangerous source of pollution for the Caspian Sea is emissions containing harmful chemicals, which include hydrocarbons, chlorine organic compounds and heavy metals. The volume of mixed oil products thrown into the sea exceeds the norm by 8 times, and phenols and heavy metals - more than 3 times. One ton of crude oil pollutes a $12 \mathrm{sq}$. $\mathrm{km}$, as a result of which the biological balance and equilibrium of the basin are disturbed. In the samples taken from the depths of the sea, oil products, phenol, and in some places, mercury were found. Contamination of deep soils has led to a decrease in organisms, and in some places - to the disappearance of deep fauna. Pollution of sea waters with oil products leads to disruption of the aeration process, as well as to the destruction of marine fauna and flora.

As noted above, the most severe and dangerous in terms of consequences is the pollution of ground and surface fresh water, as well as pollution of the marine environment, 
as is the case in the Caspian Sea, where the main objects of the oil and gas sector of Kazakhstan are concentrated. On the territory of Atyrau region there are the following surface water bodies: 4 large rivers with a total length of $1002 \mathrm{~km}$ and 9 small rivers with a total length of $348 \mathrm{~km}$, including: up to $10 \mathrm{~km}$ long - 7 rivers with a total length of $48 \mathrm{~km}$; up to $200 \mathrm{~km}-2$ rivers with a total length of $300 \mathrm{~km}$; from 200 to $500 \mathrm{~km}-1$ river $212 \mathrm{~km}$ long; over $500 \mathrm{~km}-3$ rivers. The main surface water sources of the Atyrau region are the northeastern coast of the Caspian Sea, the Zhaiyk, Uil, Emba, Sagiz rivers, the Kigach, Sharonov delta branches and other small rivers. All rivers of the Atyrau region have a transit flow from the Russian Federation and Aktobe region. The Zhaiyk River is the main source of water supply for the Caspian Lowland. It originates from the slopes of the South Ural Mountains, crosses the border of Kazakhstan, flows through the territories of the West Kazakhstan and Atyrau regions and flows into the North Caspian. The total length of Zhaiyk is $2,534 \mathrm{~km}$, on the territory of Kazakhstan $-1,084 \mathrm{~km}$, within the West Kazakhstan region $-761 \mathrm{~km}$. The total area of the river basin is $237,000 \mathrm{~km}^{2}$. The Zhaiyk River forms its flows in the upper part of the basin in the territory of the Russian Federation to the village of Kushum in the West Kazakhstan region, after which the river no longer has any tributaries. Within the West Kazakhstan region, the river receives tributaries of the Chagan, Derkul, Utva, Barbastau. The Sharonova and Kigash rivers are channels and branches of the lower reaches of the Volga River, crossing the territory of Kazakhstan and flowing into the Caspian Sea on the territory of the Atyrau region. The Emba River originates on the western slopes of the Mugodzhar mountains, crosses the territory of the Aktobe and Atyrau regions and is lost among salty coastal bogs (sors), in full-flowing years the river reaches the Caspian Sea. In the Atyrau region, the actual annual inflow of the main rivers amounted to $13,923 \mathrm{~km}^{3}$ in 2018 .

Water disposal issues are a serious problem. The current state of the sewerage networks in Atyrau makes it possible to cover only about $45 \%$ of the urban area and about $30 \%$ of the Balykshi settlement. Water disposal of the right-bank and left-bank parts of the city is carried out by separate sewerage systems. The territory of the city is characterized by a flat relief. The overwhelming majority of pumping stations are in a pre-emergency condition. The absence of sewage treatment facilities negatively affects the ecological situation in the area. If in 2017 the volume of wastewater disposal in the region amounted to 18433.91 thousand $\mathrm{m}^{3}$, then in 2018 a decrease in the volume was noted - 16971.82 thousand $\mathrm{m}^{3}$. Data on actual discharges of pollutants and water disposal are presented in table 2 [13].

Table 2. Pollution of water resources and discharges of pollutants with wastewater.

\begin{tabular}{|c|c|c|c|}
\hline \multicolumn{2}{|c|}{ Information on the actual volumes of discharges } & $\mathbf{2 0 1 7}$ & $\mathbf{2 0 1 8}$ \\
\hline \multirow{2}{*}{ Industrial discharges } & $\begin{array}{c}\text { Water disposal volume, } \\
\text { thousand m }\end{array}$ & 5010.71 & 6882.507 \\
\cline { 2 - 4 } & $\begin{array}{c}\text { Volume of pollutants, } \\
\text { thousand tons }\end{array}$ & 7.34 & 7.5 \\
\hline $\begin{array}{c}\text { Domestic waste } \\
\text { water }\end{array}$ & $\begin{array}{c}\text { Water disposal volume, } \\
\text { thousand m }\end{array}$ & 13395.07 & $10089 ., 312$ \\
\cline { 2 - 4 } & $\begin{array}{c}\text { Volume of pollutants, } \\
\text { thousand tons }\end{array}$ & 13.9 & 9.27 \\
\hline $\begin{array}{c}\text { Emergency and } \\
\text { unauthorized } \\
\text { discharges }\end{array}$ & $\begin{array}{c}\text { Water disposal volume, } \\
\text { thousand m }\end{array}$ & 28.12 & 29.1 \\
\cline { 2 - 4 } & $\begin{array}{c}\text { Volume of pollutants, } \\
\text { thousand tons }\end{array}$ & 0.04 & 16971.82 \\
\hline \multirow{2}{*}{$\begin{array}{c}\text { Total (all of the } \\
\text { above discharges }\end{array}$} & $\begin{array}{c}\text { Water disposal volume, } \\
\text { thousand m }\end{array}$ & 18433.91 & 16.8 \\
\cline { 2 - 4 } & $\begin{array}{c}\text { Volume of pollutants, } \\
\text { thousand tons }\end{array}$ & 21.9 & 0 \\
\hline
\end{tabular}


The most dangerous source of radioactive contamination in the region is the KoshkarAta tailing dump located in the Mangistau region. The Koshkar-Ata storage facility for uranium-containing waste from chemical production is the most serious environmental problem in the Western region. It is located at a distance of 7-8 km from the Caspian Sea and 3-4 km from the regional center. The drainless basin of Koshkar-Ata has been used since 1965 as a storage facility for tailings from three plants of the former giant - the Caspian Mining and Metallurgical Combine, i.e., the Chemical Hydrometallurgical Plant, a sulfuric acid plant and a nitrogen fertilizer plant for storing unused solid waste of chemical and mining and metallurgical production. The total volume of accumulated solid waste is 104.8 million tons, including 51.8 million tons of radioactive waste. According to the Ministry of Environmental Protection of the Republic of Kazakhstan, more than 400 million tons of toxic and radioactive waste are stored in the lake, including about 105 million tons of uranium production waste, 51.8 million tons of which are slightly radioactive with a total activity of 11242,825 Curies. This type of waste is a natural series of uranium-238. The most toxic of them are uranium-238, radium-226, thorium-230 [14]. This is the largest tailing dump of radioactive substances in the world - its area is $77 \mathrm{~km}^{2}$. The total area of waste disposed in it is $66 \mathrm{~km}^{2}$. The composition of the waste placed in it includes such substances as nitrates, nitrites, ammonium, iron, phosphates, fluorine, cobalt, nickel, strontium, zinc, copper, chromium, molybdenum, manganese, lead, which lie under a layer of salt water, therefore this reservoir the locals call the "dead lake" because there are no fish in it, and birds do not settle down. The area of the so-called "beaches" that are bare in the southern part of the lake, at this time, is $51 \mathrm{~km}^{2}$, the average width is $4 \mathrm{~km}$, and the length is $6 \mathrm{~km}$. (measured by satellite image). The process of intensive evaporation and the lack of volumes of incoming water led to the fact that the surface area of the settling pond decreased by $4.2 \mathrm{~km}$. These statistics will keep increasing as the process of lowering the level of the water phase continues, because the lake has no special isolation from the subsoil, which is why the "feeding" with sea water has been stopped. Groundwater contamination through underground horizons was noted for $4 \mathrm{~km}$. Many researchers have long stated about the danger of lake waters penetrating into the Caspian Sea, located nearby. The systematic study of the impact of the tailing dump on the environment and population has ceased since the early 1990s till 2002, i.e. was interrupted for almost 10 years, during which the tailing dump was degraded as a strictly controlled facility. Since the termination of the activities of production association "The Caspian Mining and Metallurgical Combine", the tailing dump continued to be used not only as a storage facility for industrial and domestic waste water, but also as a landfill for solid domestic waste, which opened free access to the tailing dump. Due to a decrease in the level of the water phase of the waste, the tailing dump dried out in places, covered with salt crust and dust (more than 10 years), and the exposed bottom sediments became sources of toxic dust due to the constantly blowing winds. Experts note that toxic dust is easily carried over long distances even in light winds. With an average wind speed in the region of 5-6 m/s and constantly blowing winds from the sea, this dust is carried far into the mainland, polluting the territory of the region. Since 2003, design work has begun on the reclamation of bare sections of the tailing dump, but, despite the measures taken, the environmental situation in and around the tailing dump remains rather difficult, because in soils for the determination of heavy metals and metalloids in the vicinity of the "Koshkar-Ata" tailing dump, there is a tendency towards an increase in the values of the content of trace elements in the soil in the direction of the prevailing winds towards st. Mangyshlak, as well as in the south-east and east directions from the tailing dump. The increased content of 205 microelements along this direction indicates deflation of contaminated sandy material and its wind transport from the bare sections of the tailing dump. As mentioned above, in the risk zone the village of Baskuduk is the closest settlement to Koshkar-Ata. The highest concentration of 
radionuclides was found here. This was shown by studies of the fur of domestic animals, as well as vegetation near the village. In general, the isotope of uranium-238, also called depleted uranium, is a by-product of the enrichment of uranium ore and is one of the strongest general cellular poisons, which, deposited on the skin and lungs when inhaled during dust transfer, causes internal radiation of the body, especially strongly affecting the kidneys at the molecular level and other internal organs associated with the circulation of intercellular fluids [15]. To stabilize the state of the tailing dump and adjacent territories, it is necessary not only to constantly monitor the deflation of radioactive and toxic material, groundwater, but also to take specific measures that require huge financial investments.

\section{Conclusion}

Thus, the issues of protection and rational use of water resources in the Republic are very urgent today. The historical burden of accumulated problems is of such a level since there has not been a year for the ecological situation in the country to improve at least once comprehensively, even despite the growth of budgetary funding for environmental protection measures. Stocks of clean water are dwindling, and problems caused by growing waste are accumulating. It is not possible to restore valuable populations of fish, primarily sturgeon. There is a lack of an ecosystem approach to the state of water bodies, which, in fact, have no owner. There is no comprehensive analysis of ecosystems state, including environmental monitoring of the Caspian Sea. There is a lack of clear forecasts and scenarios of the consequences of environmental threats for the economy, health, tourism and recreation, on the basis of which crisis situations can be prevented. Thus, the problems of shallowing mountain rivers, especially of transboundary rivers, are getting worse. If the mountain glaciers feeding the Ili, Irtysh, Syr Darya, Amu Darya and others rivers melt, it will lead to desertification, salinization, water shortages, decline in irrigation, agriculture, fishing industry, and so on. Lake Balkhash turns into an ecological disaster zone similar to the Aral Sea. For the last 14 years, the Balkhash basin has not been studied. The lake level is fed by the accelerated melting of mountain glaciers. The pollution of the lake with heavy metals and sulfites by the Balkhashtsvetmet enterprise continues, and this is 1,800 tons of dust annually. The most problematic regions remain Central Kazakhstan, regions of East Kazakhstan, Balkhash region. Such a difficult ecological situation is associated with the activities of large industrial enterprises. So, in December 2018, more than one hundred tons of fish were killed due to pollution of the Ural River by chlorine discharges, and the fish food supply suffered. The problem of threat of shallowing Lake Balkhash, the Irtysh basin, pollution of water bodies, unsuitable for fish, recreation and tourism still remains. It is necessary to return to the methodology of the National Action Plan for Environmental Protection and Sustainable Development adopted in 1998, which created a good toolkit for identifying priority environmental problems. The new edition of the Environmental Code [16], adopted in January 2021 and developed taking into account the experience of the Organization for Economic Cooperation and Development, to environmental standards of which Kazakhstan is moving, can be of great help.

\section{References}

1. National report on the state of the environment and the use of National report on the state of the environment and the use of natural resources of the Republic of Kazakhstan for 2018 (Astana, 2019)

2. M.A. Mukasheva, K.A. Nurlybaeva, A.K. Arymbekova, A.E. Starikov, International Journal of Applied and Fundamental Research 1-1, 85-88 (2017) 
3. Materials of the International Ecological Forum on the problems of Lake Balkhash (2015)

4. T. Alimbaev, Zh. Mazhitova, Ch. Beksultanova, N. Tentigul Kyzy, E3S Web of Conferences 175, 14019 (2020)

5. T. Alimbaev, Zh. Mazhitova, B. Omarova, B. Kamzaev, K. Atanakova, E3S Web of Conferences 157, 1-8 (2020)

6. National report on the state of the environment and the use of National report on the state of the environment and the use of natural resources of the Republic of Kazakhstan for 2018 (Astana, 2019)

7. Oil and gas. No. 4 (Almaty, 2014)

8. O.I. Yegorov, O.A. Chigarkina, A.S. Baimukanov, Oil and Gas Complex of Kazakhstan: Development Problems and Operational Efficiency (Atamura, Almaty, 2003)

9. T. Alimbaev, B. Omarova, B. Abzhapparova, K. Ilyassova, K. Yermagambetova, Z. Mazhitova, E3S Web of Conferences 175, 14008 (2020)

10. T. Alimbaev, Z. Mazhitova, A. Bogenbayeva, B. Omarova, E3S Web of Conferences 203, 05001 (2020)

11. Oil and gas. No. 2. Strategic goals of NC KazMunayGas (2017)

12. Yu.A. Podavalov, Ecology of oil and gas production (Infra-Engineering, Moscow, 2010)

13. National report on the state of the environment and the use of National report on the state of the environment and the use of natural resources of the Republic of Kazakhstan for 2018 (Astana, 2019)

14. Kazmunai gas annual report for 2019 (Astana, 2019)

15. A.G. Koshim, A.S. Akashova et al., Bulletin of KazNU 2/2, 38 (2013)

16. Environmental Code of the Republic of Kazakhstan. Nur-Sultan (2021) 